\title{
The influence of aquifer material to the groundwater potency in Ngawi Regency
}

\author{
Ignasius Loyola Setyawan Purnama ${ }^{1 *}$, Laelina Rahmawati $^{1}$, Vincentia Anindha Primacintya ${ }^{2}$ and Erick Febriarta $^{3}$ \\ ${ }^{1}$ Faculty of Geography, Universitas Gadjah Mada, Indonesia \\ ${ }^{2}$ Accounting Programme, Master of Science and Doctoral, Faculty of Economics and Business, Universitas Gadjah Mada, Indonesia \\ ${ }^{3}$ Faculty of Enginering, Janabadra University, Indonesia
}

\begin{abstract}
Until now, groundwater is still the main source of water for domestic needs. Unfortunately not all places can contain groundwater. Groundwater potential in an area is largely determined by the rock layers that make up the aquifer in the area. This study aims to analyze the hydrogeological conditions of the study area and to analyze the potential for groundwater in each geological unit. To achieve this goal, this study is based on the analysis of existing secondary data, such as rock type data obtained from drill data and geological maps. Apart from these data, the main secondary data from this research is geosonar measurement data that has been done previously. In this geosonar estimation, VLF (Very Low Frequency) electromagnetic technology is used, which is a geophysical method that uses very low radio communication frequency signals $(15-30 \mathrm{kHz})$ to determine the anomalies of the electrical properties of rocks. The results showed that hydrogeologically, Ngawi Regency can be divided into two, namely areas with high groundwater potency in the central and southern parts and areas with rare groundwater in the northern part. In addition, it is also known that there is a relationship between the aquifer material and the groundwater potency. Alluvial deposits which are dominated by sand and gravel have high groundwater potency, while the Kalibeng Formation which is composed of solid marl and Anggota Banyak Kalibeng Formation composed of andesite breccias is a scarce groundwater area.
\end{abstract}

Keywords: groundwater, aquifer, geosonar

\section{Introduction}

Water is a chemical compound that is only composed of two types of atoms, namely $\mathrm{H}$ and $\mathrm{O}$ atoms. The formula for water molecules is also simple, namely $\mathrm{H}_{2} \mathrm{O}$. Even so, water is one of the most important resources for human life and other living things on earth [1]. Without water, there is no life on this earth.

The existence of water on earth is determined by a process called the hydrological cycle, which is the process of circulating water on earth, from the sea to the air, rivers, lakes and back to the sea. The phenomenon of the hydrological cycle is quite complicated because it involves various processes, various stages and various changes in form. In this phenomenon the most important processes are evaporation, transpiration, rain and surface runoff, while the changes in form that occur can be in the form of liquids, solids or gases.

In accordance with the concept of the hydrological cycle, the amount of water on earth is constant. The lack and excess of water in an area is actually just a matter of its unequal distribution both spatially and in terms of time. For example, in one year the amount of water in an area is actually sufficient, but because the water becomes flooded in the rainy season, then during the dry season there is a drought. Lack and excess of water can also occur due to the unbalanced phases of its form in the hydrological cycle.

It is true that water is a natural resource that can be renewed, however the existence of water resources is not limitless. The existence of water resources is limited according to space and time, both in quantity and quality. The thing that is desired is the availability of water in sufficient quantities, available at all times and of good quality.
Generally, there are three types of water, namely rainwater, surface water (river water, lake water) and groundwater. Because of its better quality, humans prefer to use groundwater to support their daily needs than other types of water [2]. Therefore, according to [3] groundwater is the most important part of water resources. In addition, in Indonesia the use of groundwater for household needs is also preferred because of its more secure availability, which is less affected by seasonal differences.

Currently, integrated and sustainable water resource management (including groundwater) has become a major issue for the world community [4]. In water management efforts, the assessment of groundwater potential is important [5].

Unfortunately not all places have adequate groundwater content. The size of the groundwater content in a place depends on the presence of rock layers that can store water [6]. The properties of rock that greatly affect its ability to store and transmit groundwater are its porosity and permeability. It can be seen that groundwater potency in an area is largely determined by the aquifer material in the area [7].

Sand and loose gravel are two types of rock that have the property of being able to store water and drain the excess. Therefore, an area that has these two rock types will have the opportunity to store large amounts of water [8]. In fact, it can be said that $90 \%$ of groundwater occupies the rock layers, especially those found in alluvial deposits [9].

Apart from alluvial deposits, although most of them have lower potential, some other rock formations can also function as water storage such as limestone, volcanic rock, sandstone and igneous and metamorphic rocks. Limestone is a type of rock that has unique

*Corresponding author : Setyapurna@geo.ugm.ac.id 
properties. If in other rocks, the older the grain is, the older the limestone is, the more pores it has due to the dissolution of water. Therefore, the characteristics of limestone (density, porosity and permeability) as water storage also vary widely, especially depending on their age. At different ages the degree of compression and fracture development is usually different. In young limestone, the holes that are formed are usually microscopic in size, while in old limestone caves and rivers will be formed underground, so that old limestone has the possibility to have high groundwater potential [10].

There are various types of volcanic rock, both with affanitic and paneric grains, both those containing low or high ferromagnesian elements. Some examples of volcanic rocks are granite, syenite, diorite, trachyte, andesite and basalt. From several examples of these volcanic rocks, only basalt rock can function as a good aquifer. This is because the basalt can have many pores, leaving gas holes. In addition, basalt rock also often experiences many cracks at the time of its formation. The former gas holes and cracks will be occupied by groundwater from rainwater that falls over the basalt rocky area.

Sandstones are rocks formed by cemented sand. Because of the cement, the sandstones are in a compressed state. Likewise with conglomerate rocks. Conglomerate rocks are formed as a result of cemented rounded gravel and crust. However, if the rock has experienced a lot of cracks, it will also be able to store water even in a limited amount.

Ngawi Regency is one of the regency in East Java Province whose territory borders the Province of Central Java. Astronomically this district is located at $110^{\circ} 10^{\prime}-111^{\circ} 40^{\prime}$ East Longitude and $7^{\circ} 21^{\prime}-7^{\circ} 31^{\prime}$ South Latitude, while administratively divided into 19 districts. The area of Ngawi Regency is $1,295.98 \mathrm{~km}^{2}$.

Based on the topography, in general it varies considerably from flat, wavy, hilly to high mountains, with an altitude between $40 \mathrm{~m}$ to $3,031 \mathrm{~m}$ above sea level. In the middle is a plain area which is fertile agricultural land, in the south it is a hilly and mountainous area, while in the north it is a row of the Kendeng Mountains with limestone rocks which are less fertile.

Ngawi Regency is one of the districts in East Java Province whose territory borders the Province of Central Java. Astronomically this district is located at $110^{\circ} 10^{\prime}-111^{\circ} 40^{\prime}$ East Longitude and $7^{\circ} 21^{\prime}-7^{\circ} 31^{\prime}$ LS, while administratively divided into 19 districts. The area of Ngawi Regency is $1,295.98 \mathrm{~km}^{2}$.

Based on the topography, in general it varies considerably from flat, wavy, hilly to high mountains, with an altitude between $40 \mathrm{~m}$ to $3,031 \mathrm{~m}$ above sea level. In the middle is a plain area which is fertile agricultural land, in the south it is a hilly and mountainous area, while in the north it is a row of the Kendeng Mountains with limestone rocks which are less fertile.

Judging from its physiographic condition, Ngawi Regency is located in the central depression zone of Java Island [11]. The designation as a depression zone refers to the basin area between the mountainous geography of the north and south of this district. In more detail, regionally, the physiography of Ngawi Regency can be divided into 3 parts. The southern part is an area that is still influenced by the physiographic formation of quaternary volcanoes, the middle part is influenced by fluvial processes, while the northern part is in the form of the Kendeng anticlinorium.

Judging from the lithology, the rocks that make up Ngawi Regency are several groups of Quaternary and Tertiary Rock Formations from the Late Miocene to the Holocene Period. Late Miocene lithology is dominated by rock formation groups that are in the physiography of the northern side of this district, while on the south side it tends to be a group of rocks with a younger age, namely Pleistocene to Holocene age. It is possible that different types of constituent rocks will affect groundwater conditions in this regency, because the presence and size of groundwater content in a place is highly dependent on the presence of rock layers that are capable of storing water. The purpose of this study is to analyze the hydrogeological conditions of the study area and to analyze the potential for groundwater in each geological unit

\section{Methodology}

This research is based on the analysis of existing secondary data, such as rock type data obtained from drill data and geological maps. Apart from these data, the main secondary data from this research is geosonar sounding data that has been done previously. In this geosonic estimation, VLF (Very Low Frequency) electromagnetic technology is used, which is one of the geophysical methods that determines the anomalies of the electrical properties of the ground/bedrock using very low radio communication frequency signals (15$30 \mathrm{kHz}$ ).

The principle of VLF is to measure the disturbance in the magnetic field from radio waves, which is caused by subsurface geological features, so that by analyzing the nature of the magnetic field interference, anomalous areas below the surface can be identified. The magnetic field emitted by the sonar transmitter causes an electric current which will induce a conductive geological unit, so that Eddy currents will arise in the secondary magnetic field. This secondary magnetic field will then interact with the main magnetic field originating from the transmitter which will then create a disturbed magnetic field due to shifting of phrases and changing directional orientation of the main field. The disturbed magnetic field is measured by the VLF receiver and because this disturbance is caused by subsurface conditions, it is possible to interpret the subsurface conditions including groundwater conditions from the nature of the disturbance.

To determine the hydrogeological condition of the research area, a qualitative descriptive analysis was carried out based on geological and hydrogeological data, while to determine the influence of aquifer material to groundwater potency, a quantitative descriptive analysis was carried out with the help of 
tables. Furthermore, from the two analyzes, an integrated analysis can be carried out related to the groundwater potency in the research area.

\section{Result and discussion}

\subsection{The geology of Ngawi Regency}

Rock is a collection of similar or non-similar minerals that are bonded loosely or solidly. Based on their genesis, rocks can be grouped into igneous, sedimentary and metamorphic rocks. Igneous rock is rock that occurs from freezing liquid silica solution and incandescent known as magma [12]. Sedimentary rocks are rocks formed from rocks that have existed as a result of the denudation process, the result of chemical reactions or the activity of organisms [13]. Metamorphic rocks are rocks that come from other rocks that experience changes in texture and mineral composition in the solid phase as a result of changes in physical conditions in the form of pressure, temperature or both.

Based on its texture, igneous rocks can be divided into faneric igneous rocks, porphyritic igneous rocks and affanitic igneous rocks. Examples of igneous rock from acidic to ultra-alkaline are granite, syenite, diorite, gabbro as well as peridodite and serpentine. Examples of porphyritic igneous rocks ranging from acidic to alkaline are micro granite, micro syenite, micro diorite and dolerite, while examples of affanitic igneous rocks ranging from acidic to alkaline are obsidian rhyolite, trachyte, andesite and basalt. Apart from these three types of igneous rock, there are also known pyroclastic igneous rocks resulting from volcanic eruptions in the form of ash, lapilli and bomb.

Sedimentary rocks can be divided into 2 types, namely clastic sedimentary rocks and non-clastic sedimentary rocks. Clastic sedimentary rocks are formed from re-deposition of detritus/original rock fragments through a process of compaction, cementation, recrystallization, autogenesis and metasomatism. Examples of clastic sedimentary rocks are shale, argillite, sandstone, orthokuarsite, graywacke, breccia and conglomerates.

Non-clastic sedimentary rocks are formed as a result of chemical reactions or from the activities of organisms such as evaporite sediments, precipitation sediments and coal sediments. Examples of evaporite sediments are gypsum and salt rock (halite). Examples of precipitation sediments are limestone, travertine and tuff, while examples of coal sediments are coal, black shale and bitumen.

Based on their structure, metamorphic rocks can be divided into metamorphic rocks and non-foliated metamorphic rocks. Examples of metamorphic foliated rocks are marble, hornstone, quartzite and granulite, while examples of non-foliated metamorphic rocks are slate, philit, milonite, skis, gneis and migmatics.

Physiography of Ngawi Regency according to [11] is the central depression zone of Java Island. This depression zone refers to the basin area between the north and south positive hysiography of this regency. Regionally Ngawi Regency has a physiography that is divided into 3 parts from the south to the north. The south side is the part that is still influenced by the physiographic formation of quaternary volcanoes. While the northern part is filled with physiography in the form of the Kendeng Anticlinorium.

Regionally, the structural condition of Ngawi Regency has a geological structure that is clustered on the south and north sides. The south side is indicated in the form of a fault structure that is in an area that is still affected by the fault group around Lawu Volcano. The northern side of Ngawi Regency is dominated by a regional structure in the form of folds and there are shear and upward faults. This condition cannot be separated from the physiographic conditions of the northern side of this district which are a row of hills which are part of the Kendeng Anticlinorium.

According to Geological Map, the lithology of Ngawi Regency consists of several groups of quaternary and tertiary rock formations that are scattered in the study area. The age of the lithology that is scattered in this regency ranges from the age of the rocks during the late Miocene to the Holocene. Late Miocene lithology is dominated by rock formation groups located in the physiography of the north side of this regency. Meanwhile, the south side tends to be a group of rocks with formations ranging from plistocene to holocene. The rock formations and rock groups that have a wide distribution in Ngawi Regency are (1) Alluvial Deposits which are composed of clay, silt, sand and gravel. This rock formation is deposited along the floodplains of the Lusi, Wulung and Bengawan Solo rivers. (2) Lawu Deposits are composed of volcanic sandstones, volcanic siltstone, volcanic breccia and lava. This rock formation overlaps the older formation in the southern Kendeng Lane, (3) the Tambakromo Formation which is composed of claystone, marl and limestone. Claystone is dark gray, soft, non-layered, in some places a sandy texture. Marl is light gray in color, as a thin insert $(2-8 \mathrm{~cm})$. Limestone is light gray, as a thin insert $(2-8 \mathrm{~cm})$ containing fossils of Cibicides, Robulus, Rotalia beccarii, Globorotalia tosaensis, Globorotalia truncatulinoides, Globigerinoides fistulosus and Pulleniatina obliquiloculata. This formation is in the Late Pliocene upper-Plistocene age with a sedimentary environment in neritic, 350 meters thick and overlaps in line with the Selorejo Formation, (4) the Kalibeng Formation composed of solid marl and local sandstone insertions $(20-50 \mathrm{~cm})$, which are tuff and limestone. In several places at the bottom and middle there are breccias which are multi-member and at the top of the limestone clitic members. This formation contains bentonic foraminifera including Cassidulina, Cibicides, Nodosaria and Planulina. Planktonic foraminifera fossils are Globorotalia crassaformis, Globorotalia plesiotumida, Globorotalia tosaensis and Pulleniatina obliquiloculata which show the age of the Late Miocene-Early Pliocene with a depositional environment in the upper deep-bathial neritic. It is up to 5000 meters thick and overlaps in harmony with the Kerek Formation and (5) Anggota Banyak of Kalibeng Formations consisting of andesite breccias, light gray in color, andesite fragments with a little tuff, fragment 
size 0.3-12 cm, hard, open-packed, solid. Tuff breccia gray-white, tufa fragments and a little andesite, fragment size $0.2-10 \mathrm{~cm}$, open box, solid. Underwater channel depositional environment with a thickness of between 8-25 meters.

\subsection{Aquifer discharge from geosonar measurement results}

To determine the groundwater potency in the study area, 66 geosonar soundings points were carried out. Determination of measurement points is carried out based on the extent of rock formations. The measurement results are shown in Figure 1 and Table 1.

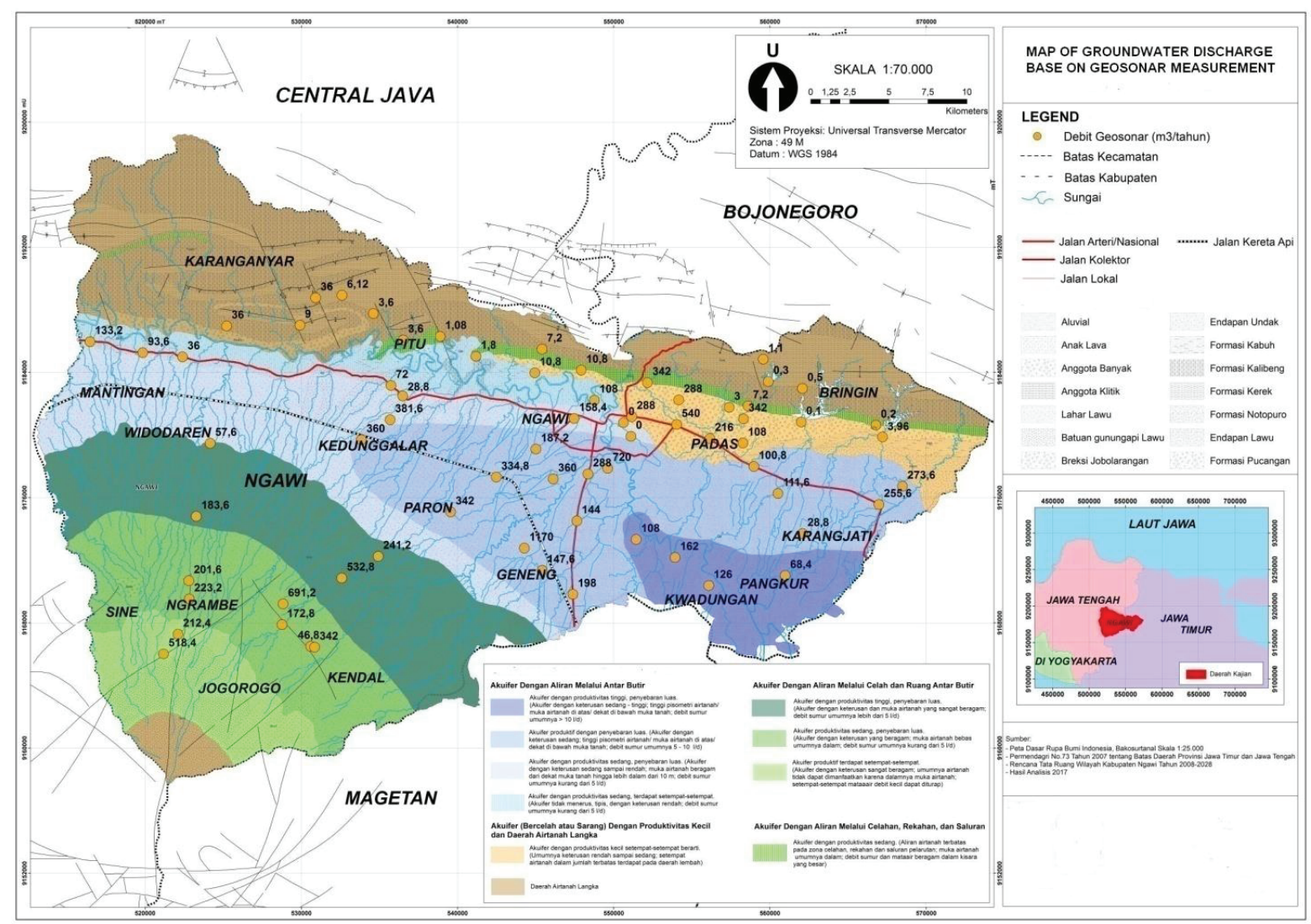

Fig. 1. Location of geosonar soundings

Table 1. The relationship between aquifer material and groundwater potency in Ngawi Regency

\begin{tabular}{|c|c|c|c|c|}
\hline \multirow{2}{*}{$\begin{array}{l}\text { Rock } \\
\text { Formation }\end{array}$} & \multirow{2}{*}{ Material } & \multicolumn{2}{|c|}{ Data from Hydrogeological Map } & \multirow{2}{*}{$\begin{array}{c}\text { Groundwater } \\
\text { Discharge }\left(\mathrm{m}^{3} / \text { year }\right)\end{array}$} \\
\hline & & Aquifer Characteristic & Aquifer Productivity & \\
\hline \multirow[t]{3}{*}{ Lawu Deposit } & \multirow[t]{3}{*}{$\begin{array}{l}\text { Volcanic sandstones, } \\
\text { volcanic siltstone, } \\
\text { volcanic breccia and } \\
\text { lava. }\end{array}$} & \multirow[t]{3}{*}{$\begin{array}{l}\text { Aquifer with flow } \\
\text { through fracture and } \\
\text { spaces between grains }\end{array}$} & $\begin{array}{l}\text { High productivity } \\
\text { with wide } \\
\text { distribution }\end{array}$ & $\begin{array}{c}57.6 \\
183.6 \\
532.8 \\
341.2 \\
\end{array}$ \\
\hline & & & $\begin{array}{l}\text { Medium productivity } \\
\text { with a wide } \\
\text { distribution }\end{array}$ & $\begin{array}{c}223.2 \\
201.6 \\
46.8 \\
342.0 \\
172.8 \\
691.2\end{array}$ \\
\hline & & & $\begin{array}{l}\text { Productive but } \\
\text { localized }\end{array}$ & $\begin{array}{l}518.4 \\
212.4 \\
\end{array}$ \\
\hline $\begin{array}{l}\text { Alluvial } \\
\text { Deposit }\end{array}$ & $\begin{array}{l}\text { Clay, silt, sand and } \\
\text { gravel }\end{array}$ & $\begin{array}{l}\text { Aquifer with flow } \\
\text { between grains }\end{array}$ & $\begin{array}{l}\text { High productivity } \\
\text { with wide } \\
\text { distribution }\end{array}$ & $\begin{array}{c}108.0 \\
162.0 \\
126.0 \\
68.4\end{array}$ \\
\hline
\end{tabular}




\begin{tabular}{|c|c|c|c|c|}
\hline & & & $\begin{array}{l}\text { Medium productivity } \\
\text { with wide } \\
\text { distribution }\end{array}$ & $\begin{array}{c}133.2 \\
93.6 \\
36.0 \\
360.0 \\
381.6 \\
28.8 \\
72.0 \\
158.4 \\
108.0\end{array}$ \\
\hline & & & $\begin{array}{l}\text { Productive with wide } \\
\text { distribution }\end{array}$ & $\begin{array}{c}342.0 \\
198.0 \\
147.6 \\
1170.0 \\
144.0 \\
334.8 \\
360.0 \\
288.0 \\
720.0 \\
187.2 \\
100.6 \\
111.6 \\
28.8 \\
255.6 \\
272.6\end{array}$ \\
\hline $\begin{array}{l}\text { Tambakromo } \\
\text { Formation }\end{array}$ & $\begin{array}{l}\text { Claystone, marl and } \\
\text { limestone }\end{array}$ & $\begin{array}{l}\text { Aquifer with joint and } \\
\text { diaklas }\end{array}$ & $\begin{array}{l}\text { Little local } \\
\text { productivity matters }\end{array}$ & $\begin{array}{c}288.0 \\
342.0 \\
288.0 \\
540.0 \\
216.0 \\
108.0 \\
342.0 \\
3.9 \\
3.0 \\
0.1\end{array}$ \\
\hline $\begin{array}{l}\text { Kalibeng } \\
\text { Formation }\end{array}$ & $\begin{array}{l}\text { Marl, solid and local } \\
\text { sandstone inserts are } \\
\text { tuff and limestone }\end{array}$ & $\begin{array}{l}\text { Aquifer with joint and } \\
\text { diaklas }\end{array}$ & $\begin{array}{l}\text { Area with scarce } \\
\text { groundwater }\end{array}$ & $\begin{array}{c}36.0 \\
9.0 \\
36.0 \\
6.12 \\
3.6 \\
3.6 \\
1.1 \\
1.8 \\
7.2 \\
10.2 \\
10.8\end{array}$ \\
\hline $\begin{array}{l}\text { Anggota } \\
\text { Banyak } \\
\text { Kalibeng } \\
\text { Formation }\end{array}$ & $\begin{array}{l}\text { Andesite breccias, } \\
\text { andesite fragments } \\
\text { with a little tuff, tuff } \\
\text { breccias, tuff } \\
\text { fragments and a little } \\
\text { andesite }\end{array}$ & $\begin{array}{l}\text { Aquifer with joint and } \\
\text { diaklas }\end{array}$ & $\begin{array}{l}\text { Area with scarce } \\
\text { groundwater }\end{array}$ & $\begin{array}{l}7.2 \\
1.1 \\
0.3 \\
0.5 \\
0.2\end{array}$ \\
\hline
\end{tabular}

Base on Figure 1 and Table 1, it can be seen that the Lawu Sediment with volcanic sandstone aquifer, volcanic siltstone, volcanic breccia and lava is the aquifer with the highest groundwater potency with an average discharge of $307.9 \mathrm{~m}^{3} /$ year. Next is the Tambakromo Formation with aquifer material are claystone aquifer, marl and limestone which has an average discharge of $213.1 \mathrm{~m}^{3} /$ year. Followed by Alluvial Deposits with aquifer material are clay aquifer, silt, sand and gravel having an average discharge of $193.1 \mathrm{~m} 3$ / year.

After these three rock formations, other rock formations in Ngawi Regency are the Kalibeng Formation and the Anggota Banyak of the Kalibeng Formation. The Kalibeng Formation is composed of solid marl and local sandstone inserts that are tuff and limestone, while the Anggota Banyak of the Kalibeng Formation are composed of andesite breccias, andesite 
fragments with little tuff, tufa breccias, tuff fragments and a little andesite. Both of these rock formations are scarce groundwater areas indicated by the average aquifer discharge of $11.4 \mathrm{~m}^{3} /$ year and $1.86 \mathrm{~m}^{3} /$ year.

Based on this description, it can be said that there is a relationship between the aquifer material with the groundwater potency in the study area. Alluvial Deposits which are composed of sand and gravel have high groundwater potency. However, Lawu Sediment which is an aquifer with flow through fracture and spaces between grains and the Tambakromo Formation, which is a joint and diaklas aquifer, can also be an aquifer with high groundwater potency.

\section{Conclusion}

1) Hydrogeologically, Ngawi Regency can be divided into two area, i.e. areas with high groundwater potency that located in the central and southern parts and areas with scarce groundwater in the northern part.

2) There is a relationship between aquifer material and the potency of groundwater. Alluvial Deposits which are dominated by sand and gravel have high groundwater potential, while the Kalibeng Formation which is composed of solid marl and Anggota Banyak of the Kalibeng Formations composed of andesite breccias are scarce groundwater areas.

\section{Acknowledgement}

This manuscript is the result of research funded by the Community Fund of the Faculty of Geography, Universitas Gadjah Mada Fiscal Year 2021.

\section{References}

1. A. A. Fenta, A. Kifle, Hydrogeology Journal 23, 195-206 (2014)

2. A. M. Hoque, M. M. Hoque, K. M. Ahmed. Hydrogeology Journal 15, 1523-1534 (2007)

3. S. A. Naghibi, H. A. Pourghasemi. Environ Monit Asses 188, 44-54 (2015)

4. I. S. Al-Salamah, Y. M. Ghazaw, A. R. Ghumman. Environ Monit Assess., 173, : 851-860 (2011)

5. R. J. Lubis, Y. Sakura, R. Delinom. Hydrogeology Journal 16 (2008)

6. M. Wanielista, R. Kersten, R. Eaglin. Hydrology : Water Quantity and Quality Control. New York: John Wiley and Sons Inc. (1997)

7. D. K. Todd, L. W. Mays. Groundwater Hydrology. New York : John Wiley \& Sons (2005)

8. T. Davie. Fundamentals of Hydrology, London: Routledge, Taylor \& Francis Group, (2008).

9. C. W. Fetter, Applied Hydrogeology, New York: Macmillan Publishing Company (1988).

10. K. R. Rushton, Groundwater Hydrology : Conceptual and Computational Models, Chichester, West Sussex : John Wiley \& Sons Ltd, (2003).

11. R. W. V. Bemmelen, The Geology of Indonesia : General Geology of Indonesia and Adjacent Archipelagoes, The Hague : Martinus Nijhoff (1970)

12. D. S. Graha, Batuan dan Mineral. Bandung: Penerbit Nova (1987)

13. J. Katili, Pengantar Geologi Umum. Bandung : Balai Pendidikan Guru (1959) 